\title{
Dinamika Populasi Mikroba Tanah dan Respon Pertumbuhan Vegetatif Tanaman Jagung (Zea mays L.) Terhadap Aplikasi Amelioran Pupuk Organik
}

\author{
(Soil Microbial Population Dynamic and Vegetative Growth Response \\ of Maize (Zea mays L.) in Application of Organic Fertilizer Ameliorant) \\ Putri Kaharu*, Agustina Monalisa Tangapo, Susan Mambu \\ Program Studi Biologi, Jurusan Biologi FMIPA UNSRAT Manado, 95115 \\ Email korespondensi: khruputri99@gmail.com
}

(Article History: Received March 4, 2021; Revised March 31, 2021; Accepted April 7, 2021)

\begin{abstract}
ABSTRAK
Pemanfaatan kembali limbah pertanian sebagai pupuk organik memiliki prospek yang baik dalam meningkatkan produktivitas lahan melalui perbaikan sifat biologi tanah. Tujuan penelitian ini adalah untuk menganalisis efek pemberian amelioran pupuk organik dari limbah jagung (Zea mays L.) terhadap peningkatan jumlah populasi mikroba tanah dan pertumbuhan tanaman jagung. Metode penelitian yang digunakan adalah Rancangan Acak Lengkap (RAL) yang terdiri dari 4 perlakuan dengan tiga kali ulangan: AA (Amelioran pupuk organik jagung $40 \mathrm{~kg} / \mathrm{ha}$ ), AB (Amelioran pupuk organik jagung $80 \mathrm{~kg} / \mathrm{ha}$ ), UR (Urea $40 \mathrm{~kg} / \mathrm{ha}$ ), dan $\mathrm{K}$ (tanpa amelioran atau urea). Perhitungan jumlah koloni mikroba tanah menggunakan metode hitungan cawan. Hasil penelitian menunjukkan perlakuan amelioran pupuk organik berpengaruh signifikan terhadap populasi mikroba tanah dan pertumbuhan tanaman jagung pada parameter tinggi tanaman dan jumlah daun. Perlakuan amelioran pupuk organik jagung tidak menunjukkan pengaruh terhadap diameter batang.

Kata kunci: Amelioran; mikroba tanah; pupuk organik; Zea mays L.
\end{abstract}

\section{ABSTRACT}

The reuse of agricultural waste as organic fertilizer has good prospects in increasing land productivity by improving soil biological properties. The aims of this study was to analyze the effect of using ameliorant organic fertilizer application from corn waste to increase the number of soil microbial populations and the growth of maize plants (Zea mays L.). The method was using CRD (Complete Random Design), which consist of 4 treatments with three repetitions: AA (Ameliorant corn organic fertilizer $40 \mathrm{~kg} / \mathrm{ha}$ ), AB (Ameliorant corn organic fertilizer $80 \mathrm{~kg} / \mathrm{ha}$ ), UR (Urea $40 \mathrm{~kg} / \mathrm{ha}$ ), and $K$ (without ameliorant or urea). Calculation of the number of soil microbials colonies was using the plate count method. The results showed that the treatment of ameliorant organic fertilizer had a significant effect on soil microbials population and growth of maize on the parameters of plant height and number of leaves. The treatment of organic fertilizer ameliorant showed no effect on stem diameter.

Keywords: Ameliorant; Soil microbes; Organic fertilizer; Zea mays L.

\section{PENDAHULUAN}

Indonesia merupakan salah satu wilayah tropis dengan tanah yang berkembang dari bahan induk batuan sedimen dan bahan induk aluvial yang memiliki tingkat kesuburan alami yang rendah. Kesuburan tanah yang rendah di daerah tropis sering diakibatkan oleh faktor alam seperti erosi tanah dan pencucian hara akibat curah hujan yang cukup tinggi. Kesuburan tanah yang rendah juga sering ditandai dengan rendahnya kandungan bahan organik dalam tanah.
Tanah merupakan komponen penting bagi daya dukung lahan terhadap pemanfaatannya oleh manusia. Dalam bidang pertanian tanah merupakan faktor yang menentukan pertumbuhan dan hasil tanaman. Menurut Prabowo (2008), sistem pengelolaan tanah di Indonesia masih menerapkan sistem budidaya pertanian yang mengutamakan penggunaan pupuk anorganik, padahal penggunaan pupuk anorganik yang dilakukan secara terusmenerus dapat menyebabkan kerusakan pada sifat fisik, kimia, dan biologi tanah 
yang kemudian dapat mempengaruhi kualitas dan kesuburan tanah. Tanah yang diolah secara berlebihan dengan pupuk anorganik akan menjadikan tekstur tanah kering, dan kandungan bahan organiknya rendah (Simarmata et al. 2016). Salah satu upaya yang dapat mengatasi permasalahan menurunnya kualitas tanah akibat penggunaan pupuk anorganik adalah dengan menerapkan penggunaan bahan pembenah tanah seperti amelioran.

Pupuk organik merupakan salah satu jenis amelioran yang mengandung bahan organik dengan jumlah kandungannya yang bervariasi (Purwani dan Hartatik 2014). Penggunaan amelioran pupuk organik mempunyai prospek yang baik dalam meningkatkan produktivitas lahan melalui perbaikan sifat biologi tanah (Musnamar 2005). Tanaman jagung (Zea mays L.) merupakan komoditi hortikultura yang banyak diminati masyarakat saat ini. Di Sulawesi Utara jagung merupakan komoditi hortikultura yang banyak diusahakan oleh para petani (Hidayat 2009). Dalam budidayanya tanaman jagung memerlukan perawatan yang intensif untuk dapat tumbuh dengan baik. Salah satu hal yang perlu diperhatikan dalam pembudidayaan tanaman jagung adalah ketersediaan hara ditanah. Kurangnya ketersediaan hara di tanah dapat menjadi faktor penghambat pertumbuhan tanaman jagung. Badan Pusat Statistik Kabupaten Minahasa menunjukkan angka tingkat produksi tanaman jagung pada tahun 2012 hingga tahun 2017 mengalami fluktuatif cenderung menurun (BPS 2012; BPS 2013; BPS 2014; BPS 2015; BPS 2016; BPS 2017). Produktivitas yang cenderung menurun ini disebabkan karena banyaknya para petani yang masih menggunakan pupuk anorganik secara berlebihan. Penggunaan pupuk anorganik yang berlebihan ini dapat mengurangi tingkat kesuburan tanah (Magdalena et al. 2013).

Potensi pengembangan tanaman jagung di Sulawesi Utara yang cukup memadai tidak menutup kemungkinan adanya sisa hasil produksi yang tidak dimanfaatkan seperti limbah pertanian tanaman jagung.
Limbah tanaman jagung berupa batang dan daun cukup berpotensi digunakan kembali untuk lahan sebagai pupuk organik. Penggunaan kembali tanaman sebagai pupuk organik dianggap sebagai pendekatan yang praktis dan fungsional dalam memulihkan kesuburan tanah dari dapat meningkatkan populasi dan aktivitas mikroba tanah.

Penerapan Keberadaan mikroba tanah merupakan salah satu indikator kesuburan tanah. Secara umum dapat dikatakan bahwa tanah yang memiliki sifat fisik dan kimia yang baik dapat disebabkan oleh tingginya populasi mikroba dalam tanah. Selain itu, mikroba tanah juga memegang peranan penting dalam hal pertumbuhan dan kesehatan tanaman (Tangapo et al. 2017). Penelitian Tamtomo dan Setiawan (2016), mengamati bahwa penerapan penggunaan pupuk organik dari tanaman jagung memiliki kandungan $\mathrm{N}, \mathrm{P}, \mathrm{K}, \mathrm{Ca}$, dan $\mathrm{Mg}$ yang cukup tinggi. Penelitian lain Mambu et al. (2018), mengamati bahwa penggunaan kembali tanaman sebagai pupuk organik dapat meningkatkan pertumbuhan tanaman tebu dan aktivitas mikroba tanah seperti enzim tanah. Tujuan penelitian ini adalah untuk menganalisis efek aplikasi amelioran pupuk organik dari limbah jagung terhadap populasi mikroba dan pertumbuhan tanaman jagung (Zea mays L.) pada fase vegetatif.

\section{METODE}

\section{Waktu dan Tempat}

Penelitian ini dilaksanakan pada bulan Maret 2020 sampai Mei 2020 di lahan pertanian jagung desa kalasey dua, Kecamatan Mandolang, Kabupaten Minahasa, Sulawesi Utara. Isolasi mikroba tanah dan perhitungan jumlah koloni dilakukan di Laboratorium Lanjut Jurusan Biologi, Fakultas Matematika dan Ilmu Pengetahuan Alam, Universitas Sam Ratulangi, Manado.

\section{Cara Kerja}

Penelitian ini diawali dengan persiapan lahan selanjutnya pengukuran luas lahan, total luas lahan yang akan digunakan adalah $169 \mathrm{~m}^{2}$. Kemudian dilanjutkan dengan 
penggemburan tanah dengan kedalam 15 $20 \mathrm{~cm}$.

Amelioran pupuk organik jagung diaplikasikan 2 minggu sebelum tanam Sedangkan urea diberikan pada saat penanaman tanaman jagung, dengan cara ditugal pada petak masing-masing; AA (Amelioran pupuk organik jagung 40 $\mathrm{kg} / \mathrm{ha}$ ), 3 petak $=2,4 \mathrm{~kg} /$ petak $=7,2 \mathrm{~kg} / \mathrm{m}^{2}$, AB (Amelioran pupuk organik jagung 80 $\mathrm{kg} / \mathrm{ha}$ ), 3 petak $=4,7 \mathrm{~kg} /$ petak $=14,1 \mathrm{~kg} / \mathrm{m}^{2}$, UR (Urea $40 \mathrm{~kg} / \mathrm{ha}$ ), 3 petak $=2,4 \mathrm{~kg} /$ petak $=7,2 \mathrm{~kg} / \mathrm{m}^{2}$ Penanaman jagung dilakukan dengan pembuatan lubang tanam dengan cara ditugal dengan kedalaman $3-5 \mathrm{~cm}$ dengan jarak tanam 80 x $30 \mathrm{~cm}^{2}$. Pengambilan sampel tanah dilakukan dengan cara komposit yaitu menggabungkan sampel tanah yang diperoleh dari beberapa titik berbeda dengan kedalaman yang sama.
Perhitungan jumlah koloni menggunakan metode cawan hitung. Cawan yang dipilih dan dihitung adalah cawan petri yang mengandung koloni antara 30-300.

\section{Analisis Data}

Data yang di peroleh dianalisis menggunakan uji ANAVA meliputi populasi mikroba tanah, tinggi tanaman jagung, jumlah daun, dan diameter batang tanaman jagung.

\section{HASIL DAN PEMBAHASAN Populasi Mikroba Tanah}

Pada Tabel 1 menunjukkan bahwa adanya perbedaan jumlah populasi mikroba tanah pada tanah sebelum perlakuan dengan tanah sesudah perlakuan pada tanaman jagung umur 15 HST dan 30 HST.

Tabel 1. Jumlah Populasi Mikroba Tanah (CFU/g tanah) dan Hasil Uji BNT 5\% Populasi Mikroba Tanah pada 15 HST dan 30 HST

\begin{tabular}{|c|c|c|c|}
\hline \multicolumn{4}{|c|}{ Jumlah Populasi Mikroba Tanah (CFU/g Tanah) \pm SD } \\
\hline \multirow[t]{2}{*}{ Perlakuan } & \multicolumn{3}{|c|}{ Waktu } \\
\hline & 0 & $15 \mathrm{HST}$ & $30 \mathrm{HST}$ \\
\hline AA (Amelioran pupuk organik $40 \mathrm{~kg} / \mathrm{ha}$ ) & $2,4 \times 10^{6} \pm 45,63$ & $8,1 \times 10^{5} \pm 41,88 \mathrm{a}$ & $1,1 \times 10^{6} \pm 5,13 b$ \\
\hline AB (Amelioran pupuk organik $80 \mathrm{~kg} / \mathrm{ha}$ ) & $2,4 \times 10^{6} \pm 45,63$ & $2,9 \times 10^{8} \pm 21,78 b$ & $1,4 \times 10^{6} \pm 12,29 b$ \\
\hline UR (Urea 25\%) & $2,4 \times 10^{6} \pm 45,63$ & $8,7 \times 10^{5} \pm 36,37 \mathrm{a}$ & $1,3 \times 10^{6} \pm 26,46 b$ \\
\hline K (Kontrol) & $2,4 \times 10^{6} \pm 45,63$ & $5,6 \times 10^{5} \pm 13,05 a$ & $3,6 \times 10^{5} \pm 3,06 \mathrm{a}$ \\
\hline
\end{tabular}

Pada 15 HST dan 30 HST jumlah mikroba tanah tertinggi diperoleh dari perlakuan AB. Perlakuan AB meningkatkan jumlah populasi mikroba tanah pada $15 \mathrm{HST}$ yaitu sebesar $2,9 \times 10^{8} \mathrm{CFU} / \mathrm{g}$ tanah, namun kemudian populasinya menurun pada 30 HST yaitu $1,4 \times 10^{6} \mathrm{CFU} / \mathrm{g}$ tanah. Berbeda dengan populasi pada perlakuan AA dan UR yang meningkat pada 30 HST walaupun populasinya masih lebih rendah dari perlakuan AB. Hasil jumlah populasi mikroba tanah terendah diperoleh perlakuan K pada 15 HST dan 30 HST.

Hasil analisis sidik ragam menunjukkan perlakuan berpengaruh signifikan pada populasi mikroba tanah setelah perlakuan 15
HST (Tabel 1). Pemberian amelioran pupuk organik pada tanah menyebabkan populasi mikroba tanah meningkat mulai dari 15 HST sampai 30 HST. Data hasil perhitungan populasi mikroba tanah sebelum perlakuan memperoleh nilai $2,4 \times 10^{6} \mathrm{CFU} / \mathrm{g}$ tanah, setelah perlakuan 15 HST populasi mikroba mengalami peningkatan cukup besar pada perlakuan AB (Amelioran pupuk organik 80 $\mathrm{kg} / \mathrm{ha}$ ). Namun kemudian, populasinya menurun pada 30 HST. Peningkatan populasi mikroba pada awal masa tanam juga dilaporkan Hindersah et al. (2016), bahwa populasi bakteri tanah pada tanaman teh setelah perlakuan pupuk organik meningkat hingga $10^{7}$ pada 8 MST (Minggu 
Setelah Tanam). Penelitian lain Tangapo et al. (2018), melaporkan kelimpahan bakteri sekitar perakaran tanaman ubi jalar memuncak pada dua bulan pertama (R2) yaitu $1,31 \quad$ x $\quad 10^{7} \quad \mathrm{CFU} / \mathrm{g} \quad$ kemudian populasinya menurun pada bulan ketiga (R3) $6,6 \times 10^{6} \mathrm{CFU} / \mathrm{g}$ dan bulan keempat (R4) menjadi $5,08 \times 10^{6} \mathrm{CFU} / \mathrm{g}$.

Meningkatnya populasi mikroba tanah pada perlakuan $\mathrm{AB}$ diduga karena dosis amelioran pupuk organik $80 \mathrm{~kg} / \mathrm{ha}$ mengandung bahan organik yang cukup banyak. Penelitian Wahyuni et al. (2016), melaporkan pemberian pupuk organik sebanyak $200 \mathrm{~kg} / \mathrm{ha}$ meningkatkan populasi bakteri tanah dari $10^{-3} \mathrm{CFU} / \mathrm{mL}$ menjadi $10^{-7}$ $\mathrm{CFU} / \mathrm{mL}$. Pemberian bahan organik dari limbah pertanian efektif perannya dalam meningkatkan populasi mikroba tanah (Ekamaida 2017).

Menurut Hindersah et al. (2016), tahap pertumbuhan dan perkembangan tanaman dapat mempengaruhi jumlah populasi mikroba dalam tanah. Pertumbuhan akar yang sudah intensif dapat menyebabkan populasi mikroba tanah berkurang. Hal ini dapat disebabkan mikroba tanah sudah benar-benar menempel di perakaran dimana terdapat eksudat akar. Eksudat akar tumbuhan tingkat tinggi sangat disukai oleh bakteri penambat nitrogen yang heterotropik (Bais et al. 2006). Menurut Bunneman et al. (2005), jumlah populasi mikroba tanah yang beragam bisa disebabkan oleh faktor lingkungan yang tidak sama serta pertumbuhan dan perkembangan tanaman yang berbeda. Populasi mikroba yang tinggi mengindikasikan adanya bahan organik yang cukup, suhu yang sesuai, ketersediaan air yang cukup, dan kondisi ekologi tanah yang mendukung (Saraswati et al. 2006).

\section{Tinggi Tanaman Jagung}

Hasil penelitian menunjukkan tinggi tanaman perlakuan $\mathrm{AB}$ lebih tinggi dibandingkan perlakuan AA dan K (Tabel 2). Hal ini menunjukan bahwa perlakuan $A B$ sudah mampu meningkatkan pertumbuhan tinggi tanaman jagung pada 15 HST sampai 45 HST namun, pengaruh perlakuan UR masih lebih tinggi dan mendominasi dibandingkan dengan AB mulai dari 15 HST sampai 45 HST.

Tabel 2. Hasil Uji BNT (Bukti Nyata Terkecil) 5\% Tinggi Tanaman Jagung (Zea mays L.)

Rata-rata Tinggi Tanaman $(\mathrm{cm}) \pm \mathrm{SD}$

\begin{tabular}{lccc}
\hline \multirow{2}{*}{ Perlakuan } & \multicolumn{3}{c}{ Umur (HST) } \\
\cline { 2 - 4 } & 15 & 30 & 45 \\
\hline AA (Amelioran Pupuk Organik 40 kg/ha) & $16,17 \pm 0,32 \mathrm{a}$ & $30,41 \pm 1,25 \mathrm{a}$ & $41,49 \pm 2,05 \mathrm{a}$ \\
AB (Amelioran Pupuk Organik $80 \mathrm{~kg} / \mathrm{ha})$ & $18,03 \pm 0,36 \mathrm{~b}$ & $35,25 \pm 1,12 \mathrm{a}$ & $54,70 \pm 4,44 \mathrm{~b}$ \\
Urea 25\% & $18,74 \pm 0,66 \mathrm{~b}$ & $37,64 \pm 1,58 \mathrm{~b}$ & $98,66 \pm 5,50 \mathrm{c}$ \\
K (Kontrol) & $16,63 \pm 0,83 \mathrm{a}$ & $31,15 \pm 4,81 \mathrm{a}$ & $46,22 \pm 8,58 \mathrm{a}$ \\
\hline
\end{tabular}

Keterangan : SD = Standar Deviasi; angka yang diikuti oleh huruf yang sama tidak berbeda signifikan berdasarkan uji BNT 0, 05.

Pada masa awal pertumbuhan terlihat bahwa perlakuan amelioran pupuk organik sudah berpengaruh nyata terhadap tinggi tanaman jagung, namun pengaruh perlakuan pupuk urea masih mendominasi dan lebih tinggi dari pada perlakuan amelioran dan kontrol. Hal ini sejalan dengan yang dilaporkan Adamy et al. (2012), bahwa pengaruh pemberian pupuk organik sudah terlihat sejak 2 MST (Minggu Setelah
Tanam) namun pemberian pupuk NPK cenderung memberikan hasil yang lebih tinggi dibanding pupuk organik. Suryana (2014), juga melaporkan bahwa penggunaan pupuk organik terhadap pertumbuhan tebu memberikan hasil yang tidak berbeda dengan pengunaan pupuk anorganik dosis rekomendasi. 


\section{Jumlah Daun Tanaman Jagung}

Hasil penelitian menunjukkan pada pengamatan 15 HST pengaruh perlakuan belum menunjukkan hasil yang berbeda nyata, namun pada pengamatan 30 HST sampai 45 HST perlakuan sudah menunjukkan adanya perbedaan yang nyata. Hasil jumlah daun dengan nilai rata-rata tertinggi diperoleh perlakuan UR pada 15
HST sampai 45 HST diikuti perlakuan $\mathrm{AB}$ yang mengalami peningkatan jumlah daun pada 30 HST sampai 45 HST dan nilai ratarata pada perlakuan AA tidak jauh berbeda dengan perlakuan $A B$, sedangkan perlakuan $\mathrm{K}$ memperoleh nilai terendah pada pengamatan 15 HST sampai 45 HST (Tabel $3)$.

Tabel 3. Hasil Uji BNT (Bukti Nyata Terkecil) 5\% Jumlah Daun Tanaman Jagung (Zea mays L.)

\begin{tabular}{lccc}
\hline \multicolumn{4}{c}{ Rata-rata Jumlah Daun (helai) \pm SD } \\
\cline { 2 - 4 } \multicolumn{1}{c}{ Perlakuan } & \multicolumn{3}{c}{ Umur (HST) } \\
\cline { 2 - 4 } & $6,67 \pm 0,12 \mathrm{a}$ & $9,13 \pm 0,31 \mathrm{a}$ & $10,13 \pm 0,23 \mathrm{a}$ \\
AA (Amelioran Pupuk Organik 40 kg) & $6,67 \pm 0,12 \mathrm{a}$ & $9,33 \pm 0,23 \mathrm{a}$ & $11,07 \pm 0,76 \mathrm{a}$ \\
AB (Amelioran Pupuk Organik 80 kg) & $7,07 \pm 0,12 \mathrm{~b}$ & $10,2 \pm 0,20 \mathrm{~b}$ & $13,67 \pm 0,61 \mathrm{~b}$ \\
UR ( Urea 25\%) & $6,47 \pm 0,31 \mathrm{a}$ & $8,67 \pm 0,58 \mathrm{a}$ & $10 \pm 0,80 \mathrm{a}$ \\
K (Kontrol) &
\end{tabular}

Keterangan : $\mathrm{SD}=\quad$ Standar Deviasi; angka yang diikuti oleh huruf yang sama tidak berbeda signifikan berdasarkan uji BNT 0, 05.

Pada 15 HST sampai 45 HST menunjukkan bahwa perlakuan $\mathrm{AA}, \mathrm{AB}$, dan $\mathrm{K}$ tidak berbeda signifikan satu sama lain namun ketiga perlakuan tersebut berbeda signifikan dengan perlakuan UR. Hasil penelitian Adamy et al. (2012), menyatakan pengaruh pemberian pupuk organik granul tidak berbeda nyata dengan kontrol terhadap jumlah daun tanaman jagung. Ramadhani et al. (2019), juga melaporkan pemberian amelioran kedalam tanah tidak menunjukkan interaksi yang nyata terhadap pertumbuhan tanaman okra. Menurut Minardi et al. (2007), pupuk organik cenderung bersifat lambat dalam menyediakan hara bagi tanaman, maka dari itu penggunaan organik harus diberikan pada dosis yang tepat dan sesuai.

\section{Diameter Batang Tanaman Jagung}

Hasil penelitian menunjukan pada pengamatan 15 HST sampai 45 HST perlakuan sudah menunjukkan adanya perbedaan yang nyata. Hasil diameter batang dengan nilai rata-rata tertinggi diperoleh perlakuan UR pada 15 HST sampai 45 HST diikuti perlakuan $\mathrm{AB}$ sedangkan pada perlakuan AA memperoleh nilai terendah pada pengamatan 30 HST dan 45 HST dan perlakuan $\mathrm{K}$ memperoleh nilai terendah pada 15 HST dan mulai mengalami peningkatan pada 30 HST dan 45 HST (Tabel 4).

Tabel 4. Hasil Uji BNT (Bukti Nyata Terkecil) 5\% Diameter Batang Tanaman Jagung (Zea mays L.)

\begin{tabular}{|c|c|c|c|}
\hline \multicolumn{4}{|c|}{ Rata-rata Diameter Batang $(\mathrm{mm}) \pm \mathrm{SD}$} \\
\hline \multirow{2}{*}{ Perlakuan } & \multicolumn{3}{|c|}{ Umur (HST) } \\
\hline & 15 & 30 & 45 \\
\hline AA (Amelioran Pupuk Organik 40 kg) & $5,76 \pm 0,28$ & $10,55 \pm 0,51 \mathrm{a}$ & $14,07 \pm 1,32 \mathrm{a}$ \\
\hline AB (Amelioran Pupuk Organik 80 kg) & $5,94 \pm 0,32$ & $12,26 \pm 1,15 \mathrm{a}$ & $16,52 \pm 1,22 \mathrm{a}$ \\
\hline UR (Urea $25 \%)$ & $6,67 \pm 0,59$ & $16,43 \pm 2,87 b$ & $22,25 \pm 2,31 b$ \\
\hline K (Kontrol) & $5,7 \pm 0,70$ & $11,07 \pm 2,07 \mathrm{a}$ & $14,17 \pm 1,71 \mathrm{a}$ \\
\hline
\end{tabular}


Berdasarkan hasil uji lanjut BNT (Bukti Nyata Terkecil) 5\% (Tabel 4) pada 30 HST dan 45 HST menunjukkan bahwa perlakuan $\mathrm{AA}, \mathrm{AB}$, dan $\mathrm{K}$ tidak berbeda signifikan satu sama lain namun ketiga perlakuan tersebut berbeda signifikan dengan perlakuan UR. Hal ini sejalan dengan yang dilaporkan Adnan et al. (2015), bahwa pupuk organik, pupuk NPK dan kontrol tidak menunjukkan perbedaan yang nyata terhadap pertumbuhan bibit kelapa, kecuali pada umur 8 bulan pupuk NPK memberikan hasil yang nyata terhadap diameter batang bibit kelapa sawit. penelitian lain Mambu et al. (2018), aplikasi pupuk organik dari limbah tebu tidak menunjukan perbedaan yang nyata pada diameter batang tanaman tebu, kecuali pada jumlah daun yang meningkat sebesar $11 \%$ $20 \%$.

Menurut Dewanti (2018), pelapukan bahan organik memerlukan waktu yang relatif lebih lama dalam melepas unsur hara tersedia bagi tanaman. Kompos yang diberikan sebagai pupuk organik kedalam tanah memerlukan waktu terdekomposisi sempurna setelah berumur 6-7 minggu (Tamtomo dan Setiawan 2016).

\section{KESIMPULAN}

Berdasarkan hasil penelitian dapat disimpulkan bahwa aplikasi amelioran pupuk organik memberikan pengaruh yang nyata terhadap populasi mikroba tanah, pertumbuhan tinggi tanaman dan jumlah daun tanaman jagung namun tidak berpengaruh pada diameter batang tanaman jagung umur 15 HST. Aplikasi amelioran pupuk organik limbah jagung dosis $80 \mathrm{~kg} / \mathrm{ha}$ memberikan hasil tertinggi pada populasi mikroba tanah dan hasil yang baik pada tinggi tanaman dan jumlah daun tanaman jagung.

\section{DAFTAR PUSTAKA}

Nurhayati, Jamil L, Rizqi SA (2011) Potensi Limbah Pertanian Sebagai Pupuk Organik Lokal Di Lahan Kering Dataran Rendah Iklim Basah. Jurnal Iptek Tanaman Pangan. 6 (2): 193 202.
Hindersah R, Bagu A, Pujawati S (2016) Populasi Bakteri dan Jamur Serta Pertumbuhan Tanaman Teh (Camellia Sinensis L.) Pada Dua Jenis Media Tanam. Agrologia. 5 (1): 1 - 9.

Adamy I, Husnain, Rosminik (2012) Pengaruh Pupuk Organik Dari Berbagai Sumber Bahan Baku Terhadap Pertumbuhan Jagung (Zea mays L.). Tropical Soils. 23 (2): 583 - 590.

Adnan SI, Utoyo B, Kusumatuti A (2015) Pengaruh Pupuk NPK dan Pupuk Organik terhadap Pertumbuhan Bibit Kelapa Sawit (Elaeis guineensis Jacq.). Agro Industri Perkebunan. 3 (20): 69 81.

Badan Pusat Statistik (2005) Provinsi Sulawesi Utara Angka Tahun 2005. Manado.

Badan Pusat Statistik (2012) Minahasa dalam angka 2012. Kabupaten Minahasa.

Badan Pusat Statistik (2013) Minahasa dalam angka 2013. Kabupaten Minahasa.

Badan Pusat Statistik (2014) Minahasa dalam angka 2014. Kabupaten Minahasa.

Badan Pusat Statistik (2015) Minahasa dalam angka 2015. Kabupaten Minahasa.

Badan Pusat Statistik (2016) Minahasa dalam angka 2016. Kabupaten Minahasa.

Badan Pusat Statistik (2017) Minahasa dalam angka 2017. Kabupaten Minahasa.

Bais HT, Weir TL, Pery G, Gilroy S, Vinanco JM (2006) The Role Of Exudats In Rhizosphere Interaction With Plants And Other Organisms. Plant Biol. 57: 233 - 266.

Bunneman EK, Schwenke GD, Zwieten V (2005) Impact of Agricultural Inputs on Soil Organism. Soil Biology. 44 (4): $379-400$.

Ekamaida (2017) Menghitung Total Bakteri pada Tanah Organik Limbah Rumah Tangga dan Tanah Anorganik dengan 
Metode Total Plate Count (TPC). Jurnal Penelitian Agrisamudra. 4 (2): 87 - 91.

Hidayat A (2009) Sumberdaya Lahan Indonesia: Potensi, Permasalahan, dan Pemanfaatan. J. Sumberdaya Lahan. 3 (2): $107-117$.

Hindersah R, Bagu A, Pujawati S (2016) Populasi Bakteri dan Jamur Serta Pertumbuhan Tanaman Teh (Camellia Sinensis L.) Pada Dua Jenis Media Tanam. Agrologia. 5 (1): 1 - 9.

Mambu S, Sugihara S, Kawame T, Nishigaki T, Toyota K, Miyamaru N, Tanaka H, Kanekatsu M (2018) Effect of Green Manure Application on Soil Enzyme Activity and Nutrient Dynamics in a Sugarcane Field of Kitadaito, Okinawa, Japan. JARQ. 52 (4): $315-324$.

Magdalena F, Sudiarso, Titin S (2013) Penggunaan Pupuk Kandang dan Pupuk Hijau Crotalaria Juncea L. untuk Mengurangi Penggunaan Pupuk Anorganik pada Tanaman Jagung (Zea mays L.). J. Produksi Tanaman. 1 (2): $1-11$

Minardi S, Suntoro, Syakhfendi, Handayanto (2007) Peran Asam Humat Dan Fulfat Dari Bahan Organik Dalam Pelepasan P pada Lahan Andisol. Agrivita. 29 (1): 30 - 41.

Prabowo R (2008) Kajian Biopeptisida dan Pupuk Hayati dalam Mendukung Pengelolaan Tanaman Tomat Secara Terpadu. Jurnal Mediagro. 4 (1): 81 88.

Purwani J, Hartatik W (2014) Pengaruh Pemberian Bahan Ameliorasi Dan Pupuk Organik Pada Tanaman Kedelai Terhadap Populasi Mikroorganisme Dan Serapan Hara Nitrogen Dan Fosfor Di Lahan Kering Masam. Prosiding Seminar Hasil Penelitian Aneka Kacang dan Umbi: Bogor, 2014. Balai Penelitian Tanah. 273 - 281.

Ramadhani C, Sumardi, Murcito BG (2019) Pemberian Amelioran terhadap Pertumbuhan Tanaman Okra (Abelmoschus esculentus L.) pada Ultisol. JIPI. 21 (2): 121 - 128.
Saraswati D, Rasti N, Yuniarti E, Elsanti (2006) Bioakumulasi Kadmium di Tanah Sawah Tercemar. Prossiding Perhimpunan Mikrobiologi Indonesia: Bogor, 2006. Balai Penelitian Tanah. 1 -9 .

Simarmata T, Herdiyantoro D, Setiawan A, Suryatmana P (2016) Rekayasa Media Tanam Berbasis Bioamelioran untuk Meningkatkan Produktivitas Tanaman Pot dan Pekarangan. Jurnal Pengabdian Kepada Masyarakat. 1 (3): 196 - 201.

Suryana (2014) Pengaruh Pengelolaan Tanah dan Penambahan Abu Ketel terhadap Sifat Fisik Tanah, Pertumbuhan dan Produksi Tanaman Tebu (Saccharum officinarum L.). [Skripsi]. Fakultas Pertanian. Universitas Brawijaya. Malang.

Tamtomo F, Setiawan (2016) Penggunaan Pupuk Organik Kompos Limbah Jagung dan Pupuk Hijau (Salvinia molesta) pada Budidaya Jagung Lahan Pasang surut. J. Agrosains. 13 (2): $61-68$.

Tangapo MA (2018) Dinamika Populasi Bakteri Rhizosphere dan Endofit pada Budidaya Ubi Jalar Cilembu (Ipomoes batatas Var. Cilembu) dan Peranannya Selama proses Pascapanen. [Disertasi]. Program Studi Doktor Biologi. Institut Teknologi Bandung.

Tangapo MA, Astuti DI, Aditiawati P (2018) Dynamics and Diversity of Cultivable Rhizospheric and Endophytic Bacteria During The Growh Stages of Cilembu Sweet Potato (Ipomoea batatas L. var. cilembu). Agriculture and Natural Resources. 52: 309 - 316.

Wahyuni S, Rianto S, Munisah U, Prihasto S (2016) Pemanfaatan Pupuk Organik Untuk Meningkatkan Populasi Bakteri dan Produksi Tanaman Padi (Oryza sativa L.). Biology. 13 (1): 752 - 756. 